\title{
PENGARUH PROFITABILITAS, PERTUMBUHAN PERUSAHAAN, UKURAN PERUSAHAAN DAN STRUKTUR MODAL TERHADAP NILAI PERUSAHAAN
}

\author{
Wina Ayu Isnaeni, Suryo Budi Santoso*, Erny Rachmawati, Selamet Eko Budi Santoso
}

Affiliation:

Accounting Department, Universitas Muhammadiyah Purwokerto, Indonesia

\section{*Correspondence: \\ suryobs@gmail.com}

Article Process:

Submitted:

December 20, 2020

Reviewed:

January 9, 2021

Revised:

February 11, 2021

Accepted:

February 21, 2021

Published:

February 28, 2021

\section{Citation:}

Isnaeni, W. A., Santoso, S. B., Rachmawati, E., \& Santoso, S. E. B. (2021). Pengaruh Profitabilitas, Pertumbuhan Perusahaan, Ukuran Perusahaan Dan Struktur Modal Terhadap Nilai Perusahaan. Review of Applied Accounting Research, 2(2), 1424.

Office Address:

Jl. K.H. Ahmad Dahlan,

Dukuhwaluh, Kec.

Kembaran, Kabupaten

Banyumas, Jawa Tengah 53182

e-ISSN : 2807-8969

\begin{abstract}
Tujuan penelitian ini adalah untuk menguji pengaruh profitabilitas, pertumbuhan perusahaan, ukuran perusahaan dan struktur modal terhadap nilai perusahaan yang diproksikan dengan EPS (Earning Per Share) pada perusahaan bank umum syariah yang terdaftar di OJK periode 2015-2019. Variabel bebas dalam penelitian ini adalah profitabilitas, pertumbuhan perusahaan, ukuran perusahaan dan struktur modal, sedangkan variabel terikatnya adalah nilai perusahaan (EPS). Populasi dalam penelitian ini adalah perusahaan perbankan umum syariah periode 2015-2019. Teknik pengumpulan data yang digunakan adalah purposive sampling, sehingga diperoleh sampel sebanyak 11 perusahaan dengan 55 data yang sesuai dengan kriteria. Hasil penelitian ini menunjukkan bahwa profitabilitas berpengaruh positif terhadap nilai perusahaan, pertumbuhan perusahaan tidak berpengaruh positif terhadap nilai perusahaan, ukuran perusahaan berpengaruh positif terhadap nilai perusahaan, dan struktur modal berpengaruh negatif terhadap nilai perusahaan.
\end{abstract}

Kata kunci: profitabilitas, pertumbuhan perusahaan, ukuran perusahaan dan struktur modal terhadap nilai perusahaan

\begin{abstract}
The purpose of this study was to examine the effect of profitability, firm growth, firm size and capital structure on firm value as proxied by EPS (Earning Per Share) in Islamic commercial bank companies registered with OJK for the 2015-2019 period. The independent variables in this study are profitability, firm growth, firm size and capital structure, while the dependent variable is firm value (EPS). The population in this study were Islamic commercial banking companies in the 2015-2019 period. The data collection technique used was purposive sampling, in order to obtain a sample of 11 companies with 55 data that matched the criteria. The results of this study show that profitability has a positive effect on firm value, firm growth does not have a positive effect on firm value, firm size has a positive effect on firm value, and capital structure has a negative effect on firm value.
\end{abstract}

Keywords: profitability, company growth, company size and capital structure on company value 


\section{PENDAHULUAN}

Sebagai negara dengan penduduk muslim terbesar, sudah selayaknya Indonesia menjadi pelopor dan kiblat pengembangan keuangan syariah di dunia. Karena potensi Indonesia untuk menjadi global player keuangan syariah sangat besar diantaranya, jumlah penduduk muslim yang besar menjadi potensi nasabah industri keuangan syariah dan prospek ekonomi yang cerah, tercermin dari pertumbuhan ekonomi yang relatif tinggi. Yang ditopang oleh fudamental ekonomi yang solid. Dan juga peningkatan sovereign credit rating indonesia menjadi investment grade yang akan meningkatkan minat investor untuk berinvestasi di sektor keuangan domestik, termasuk industri keuangan syariah.

Kondisi perkembangan perbankan syariah di Indonesia tidak sesuai dengan keinginan masyarakat Indonesia yang memiliki jumlah Muslim terbanyak di Dunia (Santos, 2020). Menurut penelitian Santoso (2014) bank syariah seharusnya tumbuh lebih cepat di negara negara mayoritas Muslim, seperti Indonesia. Hal ini karena mayoritas bahwa bank syariah didasarkan pada hukum agama Islam. Oleh karena itu mereka harus dapat berkembang lebih cepat di Indonesia negara-negara dimana populasinya dominan Muslim.

Bank syariah di Indonesia memiliki dua tujuan. Pertama, untuk lebih kompetitif terhadap bank konvensional, bahkan jika mereka mungkin tidak akan menjadi alternatif bagi mereka. Mereka sekarang bermunculan berdampingan dengan bank konvensional dan menjadi pelengkap sistem keuangan baik ditingkat nasional dan tingkat global. Bank syariah berpotensi menjadi lebih menarik dan kompetitif karena secara intrinsik mereka dapat ditangkal terhadap fluktuasi pasar keuangan internasional. Tujuan kedua, bank syariah berupaya untuk disosialisasikan, untuk menyatukan diri mereka dengan pelanggan dengan kesadaran agama dan sosial (Santoso, 2016).

Nilai perusahaan yang baik akan menarik minat para investor untuk berinvestasi. Adanya investasi merupakan kekuatan penggerak utama dari setiap sistem usaha. Untuk melakukan investasi di pasar modal, para investor memerlukan informasi tentang menilaian saham dalam pengambilan keputusan investasi. Dari sudut pandang investor, prospek jangka panjang perusahaan dapat dilihat dari pertumbuhan profitabilitas perusahaan (Ukhtiana, 2018).

Beberapa faktor yang mempengaruhi nilai perusahaan antara lain profitabilitas, growth opportunity, ukuran perusahaan, dan struktur modal Menurut Agustin dkk (2016). Faktor pertama yang mempengaruhi nilai perusahaan adalah profitabilitas merupakan faktor penting di dalam manajemen keuangan dan dapat diartikan sebagai kemampuan bisnis untuk memperoleh pendapatan yang efisien dengan cara memanfaatkan aset yang dimiliki perusahaan. Profitabilitas dalam sistem keuangan islam sepenuhnya dijamin oleh pertumbuhan ekonomi riil, sementara profitabilitas dalam sistem keuangan konvensional tidak digerakan oleh sektor riil (Santoso, 2016).

Faktor kedua adalah Pertumbuhan Perusahaan. Growth Opportunity atau Pertumbuhan Perusahaan merupakan suatu keadaan dimana perusahan harus dapat menciptakan peluang di masa mendatang. Menurut Mai (2006), Growth Opportunity merupakan peluang pertumbuhan Vol.1 No.1 dimasa mendatang atau depan. Perusahaan dengan tingkat pertumbuhan yang tinggi lebih banyak membutuhkan dana di masa depan, terutama dana eksternal untuk memenuhi 
kebutuhan investasinya atau untuk kebutuhan pertumbuhan perusahaannya (Indrajaya et al, 2011).

Faktor ketiga adalah ukuran perusahaan merupakan ukuran atau besarnya aset yang dimiliki oleh suatu perusahaan (Elva, 2012). Jika ukuran perusahaan semakin besar maka perusahan akan lebih mudah masuk ke pasar modal sehingga perusahaan akan mudah mendapatkan dana dari investor. Dana yang diperoleh dapat digunakan untuk kegiatan operasional perusahaan sehari-hari sehingga pada akhirnya akan mempengaruhi nilai perusahaan. Ukuran perusahaan yang besar dan terus tumbuh bisa menggambarkan tingkat profit mendatang, kemudahan pembiayaan ini bisa mempengaruhi nilai peusahaan dan dianggap sebagai informasi yang baik bagi investor (Ta'dir dkk, 2014).

Faktor keempat adalah struktur modal. Struktur modal adalah perbandingan atau imbangan pendanaan jangka panjang perusahaan yang ditunjukkan oleh perbandingan hutang jangka panjang terhadap modal sendiri. Struktur modal merupakan salah satu keputusan keuangan yang harus dihadapi oleh manajer keuangan berkaitan dengan komposisi hutang, saham preferen, dan saham biasa yang digunakan oleh perusahaan. Riyanto (2008:22)

Penelitian ini merupakan pengembangan dari penelitian Ukhtiana (2018). Pada penelitian ini mengambil objek Bank Umum Syariah (BUS) periode 2015-2019. Rumusan masalah yang akan dibahas adalah penelitian tentang pengaruh profitabillitas, pertumbuhan perusahaan, ukuran perusahaan dan struktur modal terhadap nilai perusahaan. Berdasarkan permasalahan tersebut dapat dirumuskan pertanyaan penelitian sebagai berikut:

1. Apakah profitabilitas berpengaruh postif terhadap nilai perusahaan?

2. Apakah pertumbuhan perusahaan berpengaruh positif terhadap nilai perusahaan?

3. Apakah ukuran peerusahaan berpengaruh positif terhadap nilai perusahaan?

4. Apakah struktur modal berpengaruh negatif terhadap nilai perusahaan?

Tujuan dalam penelitian ini adalah untuk mengetahui pengaruh profitabilitas terhadap nilai perusahaan, mengetahui pengaruh pertumbuhan perusahaan terhadap nilai perusahaan, mengetahui pengaruh ukuran perusahaan terhadap nilai perusahaan, dan mengetahui pengaruh struktur modal terhadap nilai perusahaan.

\section{TINJAUAN PUSTAKA DAN PENGEMBANGAN HIPOTESIS}

\section{Trade-off Theory}

Menurut trade-off theory yang diungkapkan oleh Myers (2001), "perusahaan akan berhutang sampai pada tingkat hutang tertentu, dimana penghematan pajak (tax shields) dari tambahan hutang sama dengan biaya kesulitan keuangan (financial distress)". Trade-off theory dalam menentukan struktur modal yang optimal memasukkan beberapa faktor antara lain pajak, biaya keagenan (agency costs) dan biaya kesulitan keuangan (financial distress) tetapi tetap mempertahankan asumsi efisiensi pasar dan symmetric information sebagai imbangan dan manfaat penggunaan hutang.

\section{Signaling Theory}

Menurut Brigham dan Houston (2015), menyatakan bahwa sinyal adalah suatu tindakan yang diambil oleh manajemen perusahaan yang memberikan petunjuk bagi investor tentang bagaimana manajemen memandang prospek perusahaan. 
Berdasarkan Signaling Theory bahwa Suatu informasi yang berisi sinyal bahwa perusahaan melalui manajemen telah merealisasikan keinginan pemilik ini merupakan salah satu bentuk dari teori signaling.

\section{Profitabilitas}

Menurut Astuti (2004) menyatakan bahwa profitabilitas adalah keuntungan perusahaan yang berasal dari penjualan yang telah dilakukan. Profitabilitas berperan penting dalam semua aspek bisnis karena dapat menunjukkan efisiensi dari perusahaan dan mencerminkan kinerja perusahaan, selain itu profitabilitas juga menunjukkan bahwa perusahaan akan membagikan hasil yang semakin besar kepada investor.

\section{Pertumbuhan Peerusahaan}

Menurut Mai dan Hermuningsih (2013), Pertumbuhan perusahaan adalah merupakan peluang pertumbuhan suatu perusahaan di masa depan. Dengan nilai growth opportunity yang tinggi, perusahaan diharapkan mampu untuk mencapai dan menghasilkan keuntungan yang tinggi dimasa yang akan datang. Growth opportunity yang tinggi dapat dijadikan sebagai analisis tercapainya kemakmuran para pemegang saham.

\section{Ukuran Perusahaan}

Menurut Joni dan Lina (2010), Ukuran Perusahaan merupakan ukuran atas besarnya aset yang dimiliki perusahaan sehingga perusahaan besar umumnya mempunyai total aset yang besar pula. . Ukuran perusahaan yang besar menunjukkan perusahaan terus mengalami perkembangan sehingga investor akan merespon positif dan nilai perusahaan akan meningkat (Joni dan Lina, 2010).

\section{Struktur Modal}

Menurut Riyanto (2008), Struktur modal adalah perbandingan atau imbangan pendanaan jangka panjang perusahaan yang ditunjukkan oleh perbandingan hutang jangka panjang terhadap modal sendiri. Struktur modal merupakan salah satu keputusan keuangan yang harus dihadapi oleh manajer keuangan berkaitan dengan komposisi hutang, saham preferen, dan saham biasa yang digunakan oleh perusahaan.

\section{Nilai Perusahaan}

Nilai perusahaan dapat diperoleh melalui kinerja keuangan serta dukungan dari kinerja nonkeuangan yang dilakukan oleh perusahaan, dan merupakan sebuah kombinasi yang dapat membentuk nilai perusahaan (coporate value). EPS adalah jumlah laba perusahaan yang dibagikan kepada pemilik saham sebagai keuntungan dari setiap lembar saham yang dimiliki pemegang saham (Fahmi, 2016).

\section{PENGEMBANGAN HIPOTESIS}

\section{Pengaruh Profitabilitas terhadap Nilai Perusahaan}

RAAR Profitabilitas berperan penting dalam semua aspek bis RAAR dari perusahaan dan mencerminkan kinerja perusahaan, selain itu profitabilitas juga Vol.1 No.1 menunjukkan bahwa perusahaan akan membagikan hasil yang semakin besar kepada investor Astuti (2004). Sejalan dengan penelitian yang dilakukan oleh Haq dan Rahayu (2019). Serta Dhani dan Utami (2017) yang menunjukkan bahwa profitabilitas berpengaruh positif terhadap 
nilai perusahaan. Berdasarkan pernyataan tersebut, hipotesis pertama yang dapat diajukan adalah:

H1 : Profitabilitas berpengaruh positif signifikan terhadap nilai perusahaan.

\section{Pengaruh Pertumbuhan Perusahaan terhadap Nilai Perusahaan}

Growth Opportunity merupakan peluang pertumbuhan dimasa mendatang/depan. Perusahaan dengan tingkat pertumbuhan yang tinggi lebih banyak membutuhkan dana di masa depan, terutama dana eksternal untuk memenuhi kebutuhan investasinya atau untuk kebutuhan pertumbuhan perusahaannya (Indrajaya dkk, 2011). Jika nilai growth opportunity perusahaan tinggi maka akan berpengaruh pada nilai perusahaan, sehingga akan menarik para investor untuk berinvestasi dalam perusahaan tersebut (Safrida, 2008). Sejalan dengan penelitian yang dilakukan oleh Oktavia dan Fitria (2019) serta Tondok dkk, (2019) yang menunjukkan bahwa pertumbuhan perusahaan berpengaruh positif terhadap nilai perusahaan. Berdasarkan pernyataan tersebut, hipotesis kedua yang dapat diajukan adalah:

H2 : Pertumbuhan perusahaan berpengaruh positif signifikan terhadap nilai perusahaan.

\section{Pengaruh Ukuran Peerusahaan terhadap Nilai Perusahaan}

Ukuran perusahaan dapat di lihat besar kecilnya dengan banyaknya jumlah karyawan perusahaan itu, dapat dilihat juga dengan nilai pasar saham perusahaan dan dapat dilihat dari total penjualannya atau total asetnya. Semakin besar perusahaan, maka semakin mudah untuk mendapatkan informasi yang akan meningkatkan nilai perusahaan karena hal tersebut menentukan tingkat kepercayaan investor (Prasetyorini, 2013). Sejalan dengan penelitian yang dilakukan oleh Menurut Haq dan Rahayu (2019) serta Chusnitah dan Retnani (2017) yang menunjukkan bahwa ukuran perusahaan berpengaruh positif terhadap nilai perusahaan. Berdasarkan pernyataan tersebut, hipotesis ketiga yang dapat diajukan adalah:

H3 : Ukuran perusahaan berpengaruh positif signifikan terhadap nilai perusahaan.

\section{Pengaruh Struktur Modal terhadap Nilai Perusahaan}

Penambahan utang dapat menambah besarnya risiko pada aliran pendapatan perusahaan dimana dipengaruhi oleh faktor luar perusahaan. Sedangkan utang dapat mengakibatkan beban tetap dengan tanpa melihat seberapa besarnya pendapatan perusahaan. Dengan demikian, bertambah besarnya utang, maka semakin tinggi kemungkinan kebangkrutan yang berhubungan dengan ketidaksanggupan perusahaan ketika membayar biaya bunga serta pokoknya Tony (2018). Sejalan dengan penelitian yang dilakukan oleh Fauzi dan Aji (2018) serta Aeni dan Asyik (2019) yang menunjukkan bahwa struktur modal berpengaruh negatif terhadap nilai perusahaan. Berdasarkan pernyataan tersebut, hipotesis keempat yang dapat diajukan adalah:

H4 : Struktur Modal berpengaruh negatif signifikan terhadap nilai perusahaan.

\section{METODE PENELITIAN}

\subsection{Populasi dan Sampel}

Populasi dalam penelitian ini adalah perusahaan Bank Umum Syariah yang terdaftar di Ototitas Jasa Keuangan pada periode 2015-2019. Berikut sampel penelitian yang digunakan 
Tabel 1. Deskripsi Pengambilan Sampel

\begin{tabular}{c|l|c|c}
\hline No & \multicolumn{1}{|c|}{ Keterangan } & $\begin{array}{c}\text { Pelanggaran } \\
\text { Kriteria }\end{array}$ & Jumlah \\
\hline 1 & $\begin{array}{l}\text { Perusahaan Bank Umum Syariah (BUS) } \\
\text { yang terdaftar di Otoritas Jasa } \\
\text { Keuangan pada periode 2015-2019 }\end{array}$ & 14 \\
\hline 2 & $\begin{array}{l}\text { Perusahaan yang menerbitkan laporan } \\
\text { keuangan (annual report) secara } \\
\text { berturut-turut di Bank Umum Syariah } \\
\text { (BUS) selama tahun 2015-2019 }\end{array}$ & $(3)$ & 11 \\
\hline 3 & $\begin{array}{l}\text { Perusahaan yang memiliki data lengkap } \\
\text { terkait dengan variabel-variabel yang } \\
\text { digunakan dalam penelitian }\end{array}$ & & 11 \\
\hline 4 & Total sampel (11x 5 tahun) & 55 \\
\hline 5 & $\begin{array}{l}\text { Jumlah data sampel yang memenuhi } \\
\text { kriteria dalam periode penelitian }\end{array}$ & & 55 \\
\hline
\end{tabular}

Sumber: OJK.co.id, 2020.

\subsection{Variabel}

Operasional variabel dalam penelitian in didefinisikan sebagai berikut:

1) Nilai Perusahaan (Y)

EPS (Earning Per Share), EPS adalah jumlah laba perusahaan yang dibagikan kepada pemilik saham sebagai keuntungan dari setiap lembar saham yang dimiliki pemegang saham (Fahmi, 2016).

$$
\mathrm{EPS}=\frac{\text { LabaBersih Setelah Pajak }}{\text { Jumlah Saham Beredar }}
$$

2) Profitabilitas (X1)

Profitabilitas dihitung dengan Earning Before Tax (Laba Sebelum Pajak) dan Total Asset pada perusahaan. Menurut surat edaran OJK (2019). ROA dapat diukur menggunakan rumus sebagai berikut:

$$
\text { ROA }=\frac{\text { Laba Sebelum Pajak }}{\text { Total Asset }}
$$

3) Pertumbuhan Perusahaan (X2)

Pertumbuhan aktiva adalah selisih total aktiva yang dimiliki perusahaan pada periode sekarang dengan periode sebelumnya terhadap total aktiva periode sebelumnya. Adapun rumus dari variabel ini adalah:

$$
G R O W T H=\frac{\text { Total Aktiva } \mathrm{t}-\text { Total Aktiva } \mathrm{t}-1}{\text { Total Aktiva } \mathrm{t}-1}
$$


4) Ukuran Perusahaan (X3)

Besar kecilnya perusahaan berdasarkan total aset yang dimiliki perusahaan dapat megambarkan ukuran perusahaan tersebut. ukuran perusahaan dapat diukur dengan menggunakan rumus sebagai berikut:

$$
\text { Firm Size }=\text { Ln(Total Asset })
$$

5) Struktur modal (X4)

Rasio hutang terdapat ekuitas (DER) merupakan rasio yang mengukur sejauh mana besarnya hutang dapat ditutup dengan modal sendiri (Budiyono dan Santoso 2019).

Debt to Equity Ratio (DER) dapat digunakan untuk mengukur besarnya tingkat struktur modal, rumusnya sebagai berikut:

$$
\text { DER }=\frac{\text { Total Hutang }}{\text { Total Ekuitas }}
$$

\section{Data dan Metode Pengambilan Data}

Data yang digunakan dalam penelitian ini adalah data kuantitatif dimana menggunakan data sekunder. Metode pengumpulan data yang dilakukan yaitu laporan keuangan tahunan yang diperoleh dari www.ojk.ac.id dan website resmi perusahaan Bank Umum Syariah yang terdaftar dalam OJK Indonesia pada tahun 2015-2019.

\section{MODEL REGRESI}

Penelitian ini menggunakan regresi linier berganda. Model persamaan yang digunakan sebagai berikut:

$\mathrm{NP}=\alpha+\beta_{1} \mathrm{PRO}+\beta_{2} \mathrm{PP}+\beta_{3} \mathrm{UP}+\beta_{4} \mathrm{SM}-\mathrm{e}$

Keterangan:

NP = Nilai Perusahaan

$\alpha \quad=$ Konstanta

$\beta_{1-} \beta_{4}=$ Koefisien Regresi

PRO = Profitabilitas

$\mathrm{PP} \quad=$ Pertumbuhan Perusahaan

UP = Ukuran Perusahaan

$\mathrm{SM}=$ Struktur Modal

$\mathrm{E} \quad=$ Error

\section{HASIL PENGUJIAN HIPOTESIS DAN PEMBAHASAN}

\section{Uji Statistik Deskriptif}

Tabel 2 menampilkan hasil dari uji statistik deskriptif. Profitabilitas memiliki nilai rata-rata sebesar 1,2656. Pertumbuhan Perusahaan memiliki nilai rata-rata sebesar0,1265. Ukuran Perusahaan memiliki nilai rata-rata sebesar 30,1847. Struktur Modal memiliki nilai rata-rata sebesar 141,1544. Nilai Perusahaan memiliki nilai rata-rata sebesar 19521,5098. Hasil statistik deskriptif dapat dilihat pada tabel 2 .

RAAR Vol.1 No.1 
Tabel 2. Statistik Deskriptif

\section{Descriptive Statistics}

\begin{tabular}{l|r|r|r|r|r}
\hline & \multicolumn{1}{|c|}{$\mathrm{N}$} & \multicolumn{1}{|c|}{ Minimum } & Maximum & \multicolumn{1}{c|}{ Mean } & \multicolumn{1}{c}{ Std. Deviation } \\
\hline $\mathrm{X} 1$ & 55 & $-7,34$ & 12,21 & 1,2656 & 3,35663 \\
\hline $\mathrm{X} 2$ & 55 & $-0,21$ & 0,45 & 0,1265 & 0,13348 \\
\hline $\mathrm{X} 3$ & 55 & 27,95 & 32,35 & 30,1847 & 1,13474 \\
\hline $\mathrm{X} 4$ & 55 & 34,45 & 349,64 & 141,1544 & 81,27456 \\
\hline $\mathrm{Y}$ & 55 & $-150,01$ & 241116,53 & 19521,5098 & 51990,68640 \\
\hline $\begin{array}{l}\text { Valid N } \\
\text { (listwise) }\end{array}$ & 55 & & & & \\
\hline
\end{tabular}

Sumber: Output SPSS. Data diolah, 2021

\section{HASIL PENGUJIAN HIPOTESIS}

Tabel 3 menunjukkan hasil pengujian hipotesis. Pengujian hipotesis 1 bertujuan untuk mengukur pengaruh positif dari profitabilitas terhadap nilai perusahaan. Pengujian hipotesis 2 bertujuan untuk mengukur pengaruh positif dari pertumbuhan perusahaan terhadap nilai perusahaan. Pengujian hipotesis 3 bertujuan untuk mengukur pengaruh positif dari ukuran perusahaan terhadap nilai perusahaan. Pengujian hipotesis 4 bertujuan untuk mengukur pengaruh negatif struktur modal terhadap nilai peerusahaan. Hasil pengujian hipotesis dapat dilihat pada tabel 3 .

Tabel 3. Hasil Pengujian Hipotesis (Uji t)

\begin{tabular}{|c|c|c|c|c|c|c|}
\hline \multicolumn{7}{|c|}{ Coefficients $^{\mathbf{a}}$} \\
\hline & & \multicolumn{2}{|c|}{$\begin{array}{l}\text { Unstandardized } \\
\text { Coefficients }\end{array}$} & \multirow{2}{*}{$\begin{array}{c}\text { Standardized } \\
\text { Coefficients } \\
\text { Beta }\end{array}$} & \multirow[b]{2}{*}{$\mathrm{T}$} & \multirow[b]{2}{*}{ Sig. } \\
\hline \multicolumn{2}{|c|}{ Model } & $\mathrm{B}$ & Std. Error & & & \\
\hline \multirow[t]{5}{*}{1} & (Constant) & $-822,551$ & 295,045 & & $-2,788$ & 0,009 \\
\hline & $\mathrm{X} 1$ & 7,267 & 2,077 & 0,467 & 3,498 & 0,001 \\
\hline & $\mathrm{X} 2$ & 52,702 & 58,498 & 0,121 & 0,901 & 0,374 \\
\hline & X3 & 28,709 & 10,276 & 0,472 & 2,794 & 0,008 \\
\hline & $\mathrm{X} 4$ & $-0,278$ & 0,126 & $-0,382$ & $-2,206$ & 0,034 \\
\hline
\end{tabular}

Sumber : Output SPSS. Data diolah, 2021.

\section{Pengaruh Profitabilitas terhadap Nilai Perusahaan}

Diketahui bahwa variabel profitabilitas memiliki nilai $\beta_{1}$ sebesar 7,267 dengan arah positif yang berarti $>0$. Nilai thitung profitabilitas adalah sebesar 3,498 dan nilai tabel sebesar 1,688 yang berarti $t_{\text {hitung }}>t_{\text {tabel. }}$ Nilai signifikansi sebesar $0,001<0,05$. Hasilnya berarti menunjukkan bahwa profitabilitas berpengaruh positif terhadap nilai perusahaan. Dengan demikian, hipotesis pertama yang menyatakan bahwa profitabilitas berpengaruh positif teerhadap nilai perusahaan.

\section{Pengaruh Pertumbuhan Perusahaan terhadap Nilai Perusahaan}


Diketahui bahwa variabel pertumbuhan perusahaan memiliki nilai $\beta_{2}$ sebesar 52,702 dengan arah positif yang berarti $>0$. Nilai thitung pertumbuhan perusahaan adalah sebesar 0,901 dan

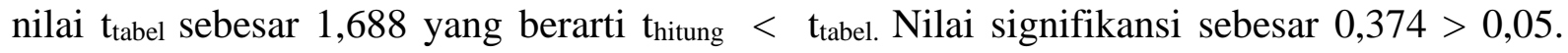
Hasilnya berarti menunjukkan bahwa pertumbuhan perusahaan tidak berpengaruh positif terhadap nilai perusahaan. Dengan demikian, hipotesis kedua yang menyatakan bahwa pertumbuhan perusahaan berpengaruh positif terhadap nilai perusahaan.

\section{Pengaruh Ukuran Perusahaan terhadap Nilai Perusahaan}

Diketahui bahwa variabel ukuran perusahaan memiliki nilai $\beta_{3}$ sebesar 28,709 dengan arah positif berarti $>0$. Nilai $t_{\text {hitung }}$ ukuran perusahaan adalah sebesar 2,794 dan nilai $t_{\text {tabel }} 1,688$ yang berarti $t_{\text {hitung }}>t_{\text {tabel }}$. Nilai signfikansi sebesar $0,008<0,05$. Hasilnya berarti menunjukkan bahwa ukuran perusahaan berpengaruh positif terhadap nilai perusahaan. Dengan demikian, hipotesis ketiga yang menyatakan bahwa ukuran perusahaan berpengaruh positif terhadap nilai perusahaan.

\section{Pengaruh struktur Modal terhadap Nilai Perusahaan}

Diketahui bahwa variabel struktur modal memiliki nilai $\beta_{4}$ sebesar $-0,278$ dengan arah negatif yang berarti $>0$. Nilai thitung struktur modal adalah sebesar -2,206 dan nilai tabel sebesar 1,688

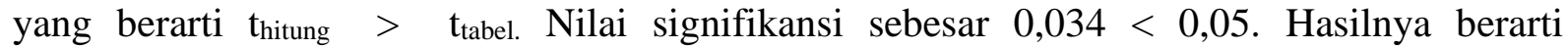
menunjukkan bahwa struktur modal berpengaruh negatif terhadap nilai perusahaan. Dengan demikian, hipotesis keempat yang menyatakan bahwa struktur modal berpengaruh negatif terhadap nilai perusahaan.

\section{KESIMPULAN}

Berdasarkan hasil analisis maka dapat ditarik kesimpulan bahwa pertumbuhan perusahaan tidak berpengaruh terhadap nilai perusahaan. Sedangkan profitabilitas, ukuran perusahaan dan struktur modal berpengaruh positif signifikan terhadap nilai perusahaan.

\section{KETERBATASAN}

Keterbatasan dalam penelitian ini adalah belum berhasil membuktikan pengaruh positif pertumbuhan perusahaan terhadap nilai perusahan dan Adanya kriteria yang menyebabkan jumlah sampel menjadi terbatas.

\section{SARAN}

Berdasarkan hasil penelitian dan pembahasan mengenai pengaruh profitabilitas, pertumbuhan peerusahaan, ukuran perusahaan dan struktur modal terhadap nilai perusahaan. Maka, penelitian dapat memberikan saran untuk dapat Menambah periode penelitian untuk sampel yang diteliti agar memperoleh hasil penelitian yang baik, Penelitian selanjutnya disarankan untuk menggunakan variabel lain yang kemungkinan memiliki pengaruh terhadap nilai perusahaan, Perusahaan bisa dilakukan pada perusahaan sektor lain selain Bank Umum Syariah, serta Penelitian selanjutnya diharapkan dapat menambah variabel yang mungkin dapat menjelaskan nilai perusahaan.

\section{DAFTAR PUSTAKA}


Aeni, N. A. M., \& Asyik, N. F. (2019). Pengaruh Profitabilitas, Pertumbuhan Perusahaan, Struktur Modal, Ukuran Perusahaan Terhadap Nilai Perusahaan. Jurnal

23 Ilmu dan Riset Akuntansi (JIRA), 8(7), 2-17

Alamsyah, H. (2012). Perkembangan dan prospek perbankan syariah Indonesia: Tantangan dalam menyongsong MEA 2015. Makalah disampaikan pada Ceramah Ilmiah Ikatan Ahli Ekonomi Islam (IAEI), Milad ke-18 IAEI,(13 April 2012).

Astuti, Dewi. 2004. Manajemen Keuangan Perusahaan. Cetakan Pertama. Jakarta: Ghalia Indonesia.

Chusnitah, N. M., \& Retnani, E. D. (2017). Pengaruh Struktur Modal, Pertumbuhan Perusahaan, Ukuran Perusahaan dan Profitabilitas terhadap Nilai Perusahaan. Jurnal

Ilmu dan Riset Akuntansi (JIRA), 6(11).

Budiyono, B., \& Santoso, S. B. (2019). The Effects of EPS, ROE, PER, NPM, and DER on the Share Price in the Jakarta Islamic Index Group in the 2014-2017 Period. Jurnal Manajemen Bisnis, 10(2), 177-191.

Dhani, I. P., \& Utama, A. G. S. (2017). Pengaruh pertumbuhan perusahaan, struktur modal,dan profitabilitas terhadap nilai perusahaan. Jurnal Riset Akuntansi dan Bisnis Airlangga, 2(1), 135-148

Elva Nuraini. (2012). Pengaruh Kepemilikan Institusional dan Ukuran Perusahaan Terhadap Kebijakan hutang dan Nilai Perusahaan (Studi pada Perusahaan Manufaktur yang Terdaftar di BEI. Jurnal Akuntansi, 4(1), 51-70.

Fahmi. (2016). Analisis Laporan Keuangan. Bandung. Alfabeta.

Fauzi, M. S., \& Aji, T. S. (2018). Pengaruh Struktur Modal, Ukuran Perusahaan, Dan Profitabilitas Terhadap Nilai Perusahaan Sektor Agriculture Tahun 20122015. Jurnal Ilmu Manajemen, 6, 1-8.

Haq, A., \& Rahayu, Y. (2019). PENGARUH PROFITABILITAS, UKURAN PERUSAHAAN, STRUKTUR MODAL DAN KEPUTUSAN INVESTASI TERHADAP NILAI PERUSAHAAN. Jurnal Ilmu dan Riset Akuntansi (JIRA), 8(1), 2-17

Hermuningsih, Sri. 2013. Pengaruh Profitabilitas, Growth Oppurtunity, Struktur Modal

Terhadap NIlai Perusahaan Publik Di Indonesia. Buletin Ekonomi Moneter dan Perbankan, 16(2),: 127-148

Indrajaya, G., Herlina. dan Setiadi. 2011. Pengaruh Struktur Aktiva, Ukuran Perusahaan, Tingkat Pertumbuhan, Profitabilitas dan Risiko Bisnis Terhadap

Struktur Modal: Studi Empiris Pada Perusahaan Sektor Pertambangan yang Listing di Bursa Efek Indonesia Periode 2004-2007. Jurnal Ilmiah Akuntansi No.6 Tahun ke-2. 1-23

Joni dan Lina. 2010. Faktor-faktor yang Mempengaruhi Struktur Modal. Jurnal Bisnis dan Akuntansi 12(2): 1-9.

Mai, M.U. 2006. Analisis Variabel-variabel yang mempengaruhi Struktur Modal Pada Perusahaan-Perusahaan LQ-45 di Bursa Efek Jakarta. Skripsi. Politeknik Negeri Bandung. Bandung.

Myers, S. C. 1984. The Capital Structure Puzzle. Journal of Finance 39 pp.575-592.

Oktavia, R., \& Fitria, A. (2019). Pengaruh Profitabilitas, Growth Opportunity, Dan Struktur Modal Terhadap Nilai Perusahaan. Jurnal Ilmu dan Riset Akuntansi (JIRA), 8(6).

RAAR Prasetyorini, B. F. 2013. Pengaruh Ukuran Perusahaan, Leverage, Price Earning Ratio dan Vol.1 No.1 Profitabilitas Terhadap Nilai Perusahaan. Jurnal Ilmu Manajemen 1(1). 183-196

Riyanto, B. 2008. Dasar-dasar Pembelanjaan Perusahaan. Edisi Keempat. Yayasan Badan Penerbit Gajah Mada. Yogyakarta. 
Riyanto, B. 2008. Dasar-dasar Pembelanjaan Perusahaan. Edisi Keempat. Yayasan Badan Penerbit Gajah Mada. Yogyakarta.

Safrida, E. 2008. Pengaruh Struktur Modal dan Pertumbuhan Perusahaan terhadap 24 Nilai Perusahaan pada Perusahaan Manufaktur di BEJ. Tesis. Sekolah Pasca Sarjana Universitas Sumatera Utara. Medan.

Santoso, S. B. (2016). Possibility of Intensifying and Socializing the Islamic Banks in Indonesia: Supporting the Indonesian Financial System Stabilization and Searching for Social Significance in the Islamic Banks in Indonesia Suryo Budi Santoso Student ID No: 1221072011 Gra. Dr. Disertation-Kanazawa Univ.-Japan., 1-235.

Santoso, SB dan Astuti, HJ. 2020. Islamic Bank Socialization Organized, Sustainable, and the Role of Reference Groups. Amerta Media. Purwokerto. Indonesia

Santoso, Suryo Budi. (2014). " Supporting factors for intensification of islamic Banking in indonesia" Graduate School of Human and SocioEnvironmental Studies. Vol 3. No. 39 Hal. 39-55.

Santoso, Suryo Budi. (2014). "An Overview of Current Banking System in Indonesia: Comparison between Conventional and Islamic Banks.Pdf." An Overview of Current Banking System in Indonesia: Comparison between Conventional and Islamic Banks. Vol. 28. Hal. 179-197.

Ta'dir Eko Prasetia, Parengkuan Tommy, dan Ivon S. Saerang. (2014). Struktur Modal, Ukuran Perusahaan dan Risiko Perusahaan Terhadap Nilai Perusahaan Otomotf yang Terdaftar di Bursa Efek Indonesia. Jurnal EMBA, 2(2), 879-889.

Tondok, B. S., Pahlevi, C., \& Aswan, A. (2019). The Influence of Capital Structure, Growth, Company Size to Profitability and Company Value of Manufacture Firms Listed in Indonesia Stock Exchange. Hasanuddin Journal of Business Strategy, 1(3), 66-78.

Ukhtiana,A., \& Widyawati, D. (2018). Pengaruh Profitabilitas, Growth Opportunity, Dan Struktur Modal Terhadap Nilai Perusahaan. Jurnal Ilmu dan Riset Akuntansi (JIRA), 7(3). 